of zirconium, as one would expect, are much less volatile than those of either titanium or silicon. For example, $\mathrm{Zr}(\mathrm{OE})_{4}$, crystallized from benzene, sublimes at $120^{\circ} \mathrm{C}$. at $10^{-6} \mathrm{~mm}$. pressure. The iso-propyl ester, with its addendum of iso-propyl alcohol, has a melting point of $138-141^{\circ} \mathrm{C}$. and the $\mathrm{Zr}\left(\mathrm{OC}_{3} \mathrm{H}_{7}-i s o\right)_{4}$ distils at $160^{\circ} \mathrm{C}$. at $0.1 \mathrm{~mm}$. pressure.

Details of this work will be published elsewhere. W. WARDLAW

Department of Chemistry, D. C. Bradley

Birkbeck College,

London, E.C.4.

Oct. 28

1 Speer, J. Org. Chem., 14, 655 (1949).

Cullinane and Chard, Nature, 164, 711 (1949).

Meerwein and Bersin, Ann., 476, 113 (1929).

\section{Orientation of Disubstituted Fluoranthene Derivatives}

Althoбgh fluoranthene is readily attacked by bromine, etc., none of the disubstituted products has been rigidly orientated. Tobler et al. ${ }^{1}$ obtained a fluoranthene disulphonic acid, which on fusion with alkali followed by oxidation gave a coloured 'chinhydronartigen' compound, and they rightly pointed out that a quinoid product would mean that sulphonation had occurred at the 4:11-positions. Their evidence, however, is not conclusive and experimental details are lacking.

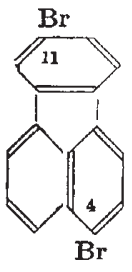

I

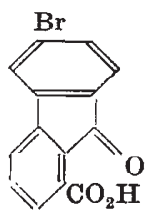

II

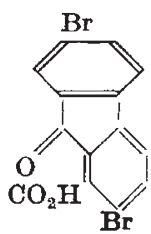

III
The bromination of fluoranthene yields a substance which we have now shown to be 4:11-dibromofluoranthene (I). Oxidation with chromic acid and acetic acid gives a monobromo compound, presumably 6-bromo-1-carboxyfluorenone (II), and 2:7-dibromo1-carboxyfluorenone (III), the constitution of which follows from its decarboxylation products. When heated with quinoline and copper bronze, it yields 2 -bromofluorenone, and it is undoubtedly the bromine atom adjacent to the carboxyl group which is removed, since under the same conditions 2-bromoand 2:7-dibromo-fluorenone are unchanged while 2-bromo-1-carboxyfluorenone and 7-bromo-1-carboxyfluorenone yield fluorenone and 2-bromofluorenone respectively. More conclusive proof of the structure of III comes from decarboxylation at $250^{\circ}$ with mercuric oxide ${ }^{2}$ to give $2: 7$-dibromofluorenone. The constitution of the original dibromofluoranthene is thus unambiguously established, and consequently other disubstituted fluoranthenes can be orientated. For example, the fluoranthene dicarboxylic acid obtained by the action of oxalyl chloride on fluoranthen $\theta^{3}$ is the $4: 11$-compound, should it be identical with the di-acid prepared from 4 : 11-dibromofluoranthene by standard methods.

Details of these and related experiments will be published elsewhere.
Thanks are expressed to the Department of Scientific and Industrial Research and to the AngloIranian Oil Co. for grants.

Neir Campbell W. W. Easton

J. RAYMENT

Chemistry Department,

University of Edinburgh. Aug. 27.

'Tobler, R., Holbro, Th., and Kern, W., Helv. Chim. Acta, 24, 101E (1941).

${ }^{2}$ Dziewonski and Khal, Chem. Abstracts, 29. 2941 (1935).
3 Campbell, N., and Easton, W. W., J. Chem. Soc., 340 (1949).

\section{Alanine and Taurine Formation from Injected Cysteine in the Rat}

THE pathways for cysteine metabolism have been studied intensively, and a great deal is known about the many reactions which lead to the formation of sulphate. Most of the studies on cysteine have been mainly concerned with the fate of sulphur; but relatively few experimental results exist concerning the fate of the carbon chain. Recently, Fromageot and Chatagner ${ }^{1}$ have furnished proof of the existence of an enzyme, desulphinicase, in liver of rabbits. This enzyme is capable of liberating sulphurous acid from L-cysteine sulphinic acid. They considered the latter compound to be the most important intermediate in the conversion of organic sulphur to inorganic sulphur ; they assumed that the splitting of sulphurous acid from L-cysteine sulphuric acid gave alanine as an intermediate. The formation of alanine from cysteine sulphinic acid has been demonstrated in rabbit liver extracts ${ }^{2}$.

Using rats of the Sprague-Dawley strain, it was possible to demonstrate in this laboratory that intravenously administered cysteine causes a significant increase in the concentration of alanine in the liver. The analyses of tissues for alanine were carried out by means of quantitative paper chromatographys. In this manner, it was possible to measure simultaneously other amino-acids present in tissues. Taurine, which unfortunately is not well separated from glycine by phenol in one-dimensional chromatograms, was also measured.

CONCENTRATION OF ALANINE AND TAURINE IN RAT LIVER AFTER OYSTRINE INJECTION

\begin{tabular}{|c|c|c|c|c|c|c|}
\hline & \multicolumn{3}{|c|}{$\underbrace{\begin{array}{c}\text { Alanine } \\
\text { (mgm. } 100 \text { gm. fresh } \\
\text { tissue) }\end{array}}_{\text {Time after injection }}$} & \multicolumn{3}{|c|}{$\begin{array}{c}\text { Taurine } \\
\text { (mgm. per } 100 \mathrm{gm} \text {. fresh } \\
\text { tissue) }\end{array}$} \\
\hline & $\begin{array}{l}\text { Time } \\
30 \\
\text { min. }\end{array}$ & $\begin{array}{l}\text { after injec } \\
60 \\
\text { min. }\end{array}$ & $\begin{array}{l}\text { tion } \\
120 \\
\min .\end{array}$ & $\begin{array}{l}\text { Time } \\
30 \\
\text { min. }\end{array}$ & $\begin{array}{c}\text { after inje } \\
60 \\
\text { min. }\end{array}$ & $\begin{array}{l}120 \\
\text { min. }\end{array}$ \\
\hline $\begin{array}{c}\text { Con- } \\
\text { trols }\end{array}$ & $41 \pm 1 \cdot 6$ & $44 \pm 3 \cdot 4$ & $43 \pm 2 \cdot 3$ & $58 \pm 2 \cdot 9$ & $60 \pm 5 \cdot 3$ & $47 \pm 5 \cdot 3$ \\
\hline $\begin{array}{l}\text { Cys- } \\
\text { teine } \\
\text { in- } \\
\text { jected }\end{array}$ & $114 \pm 1 \cdot 9$ & $97 \pm 4 \cdot 8$ & $71 \pm 2 \cdot 9$ & $143 \pm 3 \cdot 2$ & $99 \pm 3 \cdot 4$ & $99 \pm 2 \cdot \theta$ \\
\hline
\end{tabular}

* Arithmetic mesn of values from four animals plus or minus the standard errors corrected for small numbers.

The results shown in the accompanying table were obtained from groups of four animals. The concentration of the alanine and taurine-glycine fractions in the cysteine-injected groups was higher than that found in the saline-injected controls. The differences were statistically significant. This finding warrants 